\title{
The Relationship Between Language Mindsets and Feedback Preferences in L2 Writings of EFL Learners
}

\author{
Shima Vaghei, Fariba Rahimi Esfahani, Sajad Shafiee \\ Islamic Azad University \\ Correspondence concerning this article should be addressed to Fariba Rahimi Esfahani, Department of \\ English,Faculty of Humanities, Shahrekord Branch, Islamic Azad University, Shahrekord, Iran. \\ Email: rahimi_fariba@yahoo.com
}

\begin{abstract}
The present study intended to investigate intermediate Iranian EFL learners' language mindsets and examine the possible relationships between language mindsets and feedback preferences in L2 writing. To achieve these aims, 150 EFL volunteer learners were recruited from several language institutes in Isfahan, Iran, and their language proficiency level was determined through a proficiency test. The learners were then given the Language Mindsets Questionnaire and the Feedback Preferences Scale to fill out. Frequency counts, mean scores, one-sample t-tests, and SEM in Smart PLS were employed to analyze the collected data. The results of the study indicated that for the three subcomponents of the mindsets questionnaire (i.e., general language intelligence beliefs, second language aptitude beliefs, and age sensitivity beliefs about language learning), the learners did not agree (though not significantly) with the entity items, while they expressed significant agreement with the incremental items. The SEM results also revealed that the model (examining the relationship between entity/incremental mindsets and feedback preferences) indicated that entity mindsets were a significant predictor of feedback preferences, yet the incremental mindsets failed to do so. Among the feedback types, EFL learners' preferences, in a deductive order, were found to be for commentary and conferencing significantly, and then for peer correction, prompts, self-correction to a nonsignificant extent. The significance of the obtained results are presented and the implications of the study are enumerated.
\end{abstract}

Keywords: feedback preferences, L2 writing, language mindsets

\section{Introduction}

Corrective feedback (CF) has been basically conceptualized as reactions and responses to students' utterances that include errors (Ellis, 2006). It is also a compound phenomenon with several functions (Chaudron, 1988). As noted by Ellis, Loewen, and Erlam (2006), corrective feedback takes the form of answers to learner utterances that have an error. The answers can contain an indication that an error has been made, the delivery of the correct target language item, metalinguistic information about the essence of the error, or any mixture of these.

The aim of presenting feedback is to help second language (L2) students recognize a problem in their production, resulting in the correct use of the form. Corrective feedback plays a crucial role in the kind of scaffolding that teachers need to create for language learners to promote their L2 (Lyster \& Ranta, 1997; Lyster, Saito, \& Sato, 2013). Theoretical perspectives, from cognitive to social-oriented ones, suggest corrective feedback is not only helpful but also necessary for pushing students forward in their L2 growth (Lyster et al., 2013). Past research has shown that giving feedback effectively contributes to grammatical, morphological, and phonological development (Lyster et al., 2013).

CF is by no means an under-researched area of investigation in SLA as past research in the realm of feedback has focused on grammar (e.g., Ebrahimzadeh \& Khodareza, 2016; Mir \& Ghornavi, 2017; Zohdi Rad \& Ghafournia, 2017), vocabulary (e.g., Noori Khaneghah, 2016; Sippel, 2019), pronunciation (e.g., Karami \& Heidari Darani, 2018; Naeimi, Saeidi, \& Behnam, 2017), writing (e.g., Abbaspour, Atai, \& Maftoon, 2020; Gonzales, Tejeda, Krous, \& Vasquez, 2018; Rezaei, Izadpanah, \& Shahnavaz, 2017), and speaking (e.g., Farrokhi, Zohrabi, \& Chehr azad, 2018; Ramadhani, 2019; Tesnim, 2019; Zhai \& Gao, 2018) among other things. Besides, 
the ways through which learners prefer to receive feedback have attracted a great many scholars' attention as studies on written corrective feedback (e.g., Cohen \& Cavalcanti, 1990; Diab, 2005; Halimi, 2008; Lee, 2004; Leki, 1991; Rennie, 2000; Saito, 1994; Wang, 2010) and on the importance of feedback preferences by L2 learners (e.g., Diab, 2005; Ferris, 1999, 2004; Hedgcock \& Lefkowitz. 1994; Lee, 2005; Leki, 1991; Truscott, 1996, 1999) abound.

There is no escaping the fact that second language learners have different learning styles and preferences for teaching and learning (Reid, 1997; Katayama, 2007). Some scholars align with this assumption and argue that learners' undesirable feedback might not be effective for developing their writing skills as it may frustrate and demotivate them. Conversely, learners' preferred feedback can positively affect their learning and the development of their writing skills (Hedgcock \& Lefkowitz, 1996; Lee, 2005; Katayama, 2007; Schulz, 1996).

What is now missing from the colossal body of scholarly research on CF is whether feedback preferences for L2 written production vary according to the learners' personal attributes and language-learning beliefs, styles, and strategies. As an attempt to demystify this riddle, at least in part, and shed light on this rather unnoticed sphere of CF, the present study sought to examine the L2 writing feedback preferences of EFL learners who held incremental vs. entity mindsets about language learning.

The concept of mindset (MS), or implicit theories, dates back to Kelly's (1955) work, which presented some lay theories of the way people perceive the self and others. Recently, in the area of education, more concepts have been engendered via the construct of MS, in which the assumptions and beliefs of certain human traits have largely been connected to Carol Dweck and her associates' works (e.g., Blackwell, Trzesniewski, \& Dweck, 2007; Chiu, Hong, \& Dweck, 1997; Dweck, 2006; Dweck \& Molden, 2007; Dweck, Chiu, \& Hong, 1995; Hong, Chiu, \& Dweck, 1999). Additionally, mindsets have a close association with a number of theoretical and empirical studies on second language learning (e.g., Barcelos, 2003; Benson \& Lor, 1999; Cotterall, 1999; Horwitz, 1998; White, 2008) where the relationships between mindsets and language-learning behavior have been investigated.

Within the context of language learning, the fixed MS (alternatively referred to as entity MS) belief in language learning depends on a fixed and inborn talent, while the growth MS (alternatively called incremental MS) belief depends on controllable factors such as hard work and continuous training. In the area of foreign language teaching and learning, it is common for people to possess the belief that some people are born with a special talent in a certain domain (Mercer \& Ryan, 2010), which is called aptitude, and its development in language learning is significant (Robinson, 2005; Sternberg, 2002). People with an entity MS may hold the belief that having a 'gift' for languages is important when learning a language; therefore, it is a waste of effort to attempt to improve the language in question since it is impossible for poor language learners to develop as a linguist by any means (Mercer, 2012). In this regard, the aptitude of individuals with an entity or incremental MS could be observed to have different learning outcomes.

The current study addressed language mindsets as a new addition to the literature of second language acquisition, examining the links between foreign language (FL) learners' different mindsets and their different feedback preferences in relation to L2 writing.

\section{Literature Review}

\section{Language Mindsets}

The concept of mindsets, or implicit theories, generally refers to people's tacit beliefs about whether human attributes like intelligence, personality, capabilities, and so on are fixed or malleable (Dweck, 2007). Fixed mindsets (alternatively referred to as entity theories) are the beliefs that a person's abilities or attributes are predetermined and hence cannot be subject to change, while growth mindsets (alternatively called incremental theories) are the beliefs that a person's qualities are apt to be cultivated by means of hard work and the application of strategies. Such mindsets can help students set reasonable goals and take appropriate actions in different learning situations, thus guiding them to different achievement outcomes (Dweck \& Leggett, 1988). More specifically, students who strongly hold an entity mindset tend to set more performance goals and prove their ability via performance. They see criticism as evidence of a lack of capability and view challenges as 
threats to their sense of achievement. In order to preclude their self-esteem from negative performance and feedback, they shun demanding tasks, even tasks that are likely to ameliorate their ability. On the contrary, chances are that students who have a strong incremental mindset set learning goals and concentrate on their improvement and learning processes. They see overcoming problems and challenges as a way of developing their talents and use negative feedback as a means to improve. In comparison with the students with strong fixed mindset, those students who have a strong growth mindset are more likely to welcome challenges and deal with failure situations more positively. Consequently, growth mindsets are arguably a key to students' perseverance and long-term achievement (Yeager \& Dweck, 2012).

The trait of mindsets and their impacts have been extensively studied over the past two decades in many educational areas like math and science, which provided far-reaching implications for academic achievement and success in education (see Burnette, O’Boyle, VanEpps, Pollack, \& Finkel, 2013 for a meta-analysis). Recent studies in the domain of language learning have started to examine the conceptualization and motivational impacts of language mindsets (see Lou \& Noels, 2016; Mercer \& Ryan, 2010). Given that mindsets are domainspecific beliefs, language mindsets, or the beliefs about whether the ability to learn a second language is fixed or can be developed, are shown to be only moderately correlated with mindsets in other areas, such as abilities to learn math and/or sports (see Lou \& Noels, 2017). Such findings imply that most students probably hold a mixture of fixed and growth mindsets in different domains (Dweck, 2019). As the mindsets that people hold orient their approach to the learning task at hand (Lou, 2014), different types of mindsets are likely to cause EFL learners to perceive learning-related issues differently and employ certain types of learning styles and strategies; hence, they are arguably apt to cause language learners to welcome certain types of tendencies and preferences, including corrective feedback preferences in general and feedback on L2 writing in particular.

\section{Corrective Feedback}

Corrective feedback could be defined as "responses to learner utterances containing an error" (Ellis, 2006, p. 26); they represent a complex phenomenon that is used to perform several functions (Chaudron, 1988). The motive behind providing feedback is to help L2 students recognize a problem in their linguistic production and facilitate in the correct use of that structure. Corrective feedback has a central role in the kind of support that teachers need to provide for language learners to improve their L2 (Lyster \& Ranta, 1997; Lyster, et al., 2013).

Corrective feedback in an EFL classroom context could differ in terms of being implicit or explicit (Lyster et al., 2013). Students may be exposed to explicit corrective feedback, more often than not, in the form of metalinguistic explanation as well as explicit correction. Furthermore, implicit corrective feedback may take the form of recasts. Past research has indicated that implicit (e.g., Lyster \& Ranta, 1997; McDonough \& Mackey, 2006) and explicit corrective feedback (e.g., Carroll, Swain, \& Roberge, 1992; Ellis, 2012) have positive impacts on the acquisition of different grammatical, phonological, and morphosyntactic forms.

\section{Empirical Background}

As an example of a study on feedback preferences and their relationships with individual attributes of L2 learners, Roy's (2019) study investigated multilingual writers' preferences for audio and/or written feedback, and examined the effect of feedback format on their revision processes. To meet the aims of the study, eight multilingual writers were chosen to be interviewed and their first drafts as well as revised drafts of the final research papers for which they had received audio and written feedback were compared by means of the 'Compare' option in Microsoft Word. Additionally, an early-semester participatory survey and reflection survey were administered among the multilingual writers of the composition course. The obtained results revealed that multilingual writers expected to receive directive explicit feedback from their course instructors. They mentioned that audio feedback was far better for global commentary while written feedback was a better option better for local commentary. The participants' perceptions regarding the effectiveness of audio vs. written feedback on their revision process differed depending on their self-efficacy. No significant effect was observed for the feedback format on the participants' revision process. A positive correlation was found, however, between their preferred type of feedback and their self-perceived English listening proficiency. Those who enjoyed higher self-efficacy and were confident about their English listening proficiency preferred to be given audio feedback rather than written feedback. The obtained results could have immediate implications for L2 writing instructors. This study proposed that L2 writing instructors ought to adopt the approach of providing 
an amalgamation of feedback formats consisting of both audio and written feedback in order to promote multilingual writers' overall writing skills. It could also be suggested that L2 writing instructors ought to think about providing some relevant grammar lessons for their students in L2 writing courses. Finally, this study recommended further investigation of the potential of audio feedback in arousing student-teacher connections and relationships, especially in online composition courses.

Roy's (2019) study can provide a spark for the idea that feedback preferences could have relationships with other individual attributes (e.g., language-learning mindsets among other things). With respect to the promising results of mindset interventions in education in general, setting up interventions is a crucial direction for language education. Nonetheless, even with recent interest in mindsets in the field of SLA (Mercer \& Ryan, 2009; Lou \& Noels, 2017), there has been scant research on the nature of altering students' language mindsets and examining their relationship with other language-learning variables. Several double-blind randomized experiments in this area revealed promising results, showing that students who jotted a reflection down after reading a paper that supported the nurturing of language-learning ability confirmed growth language mindsets more strongly than those students who read and wrote about a paper that was not pertinent to language learning (e.g., Lou \& Noels, 2019a). Encouraging growth language mindsets can also end in stronger learning goals, more positive effort beliefs, and reduced levels of anxiety among ESL students in a laboratory context (Lou \& Noels, 2016, 2019a). A recent experimental study revealed that prompting growth language mindsets could decrease ESL students' feelings of rejection and trigger them to use an L2, especially among those who had lower L2 competence (Lou \& Noels, 2019c).

Lou (2014) utilized Dweck's (1999) implicit theories framework in an L2 context to figure out the causal relationships among L2 students' mindsets, goal orientations (that is, learning goals, performance-approach goals, and performance-avoidance goals), and responses to failure situations (that is, mastery responses, helpless responses, anxiety, and fear of failure). A total of 150 L2 university students were randomly assigned to two experimental conditions in which different mindsets were induced; afterwards, they filled out a questionnaire on their L2 goals and responses in failure situations. The results of the study indicated that after being primed for an incremental mindset, irrespective of their perceived L2 ability, participants set higher learning goals and, in turn, expressed more mastery-orientated responses in failure situations. On the other hand, L2 learners who were exposed to priming for an entity mindset, in cases where they perceived of themselves as highly proficient L2 users, set higher performance-approach goals and, in turn, were more fearful of failure situations.

In much the same way the present study intended to cast light on the still-enigmatic issue of CF through the lens of the individual attribute of language mindsets, Albalawi's (2017) study intended to examine the complex dynamism of L2 demotivation. This study was an attempt to modify and reform previous conceptualizations about demotivation and move L2 demotivation mainstream research into a new phase that underscored the complexity of its process as well as its development. The demotivational, motivational, and remotivational triad of L2 learners was studied through the lens of several key psychological and theoretical constructs, which included language mindsets, personality hardiness, learner helplessness, as well as an L2 motivational selfsystem. The study was conducted in two phases that examined the demotivation of female L2 university students in Saudi Arabia by using a range of research methodologies such as qualitative in-depth interviews, quantitative surveys, and SEM.

First, an exploratory qualitative study was conducted, which intended to examine the L2 learners' different perspectives on their language-learning experiences and their perceptions of different demotivating factors. Qualitative semi-structured interviews were planned and conducted with 13 English language learners and an analysis of the qualitative data unearthed that language-learning mindsets played an important part in the language learner's motivation, demotivation, remotivation, and in their resilience/vulnerability.

In the second phase of the study, confirmatory quantitative analysis was performed aiming to examine the impacts of holding a particular language-learning mindset on the learners' L2 demotivation. While making use of the key variables that emerged in the qualitative phase of the study, the researcher designed and administered a questionnaire to 2044 foundation-year university students. In fact, several tests were conducted to investigate (a) the relationships between the variables, (b) the possible differences between the growth mindset of L2 learners and the fixed mindset L2 learners, and (c) the putative differences between resilient and vulnerable L2 
learners. The results obtained from the quantitative phase of the study confirmed all the hypothesized relationships and served to establish an empirical link between L2 learning mindset and both L2 demotivation and L2 resilience.

Finally, a structural model that posited that L2 demotivation could be predicted by the fixed language-learning mindset was hypothesized. Structural equation modeling (SEM) was conducted to empirically test and examine the hypothesized model. A series of causal relationships was simultaneously examined in this model. The SEM analysis confirmed all the hypothesized causal relationships and indicated that L2 demotivation could be accounted for and predicted positively and directly by the fixed L2 learning mindset. The results also revealed that the fixed L2 learning mindset could indirectly end in L2 demotivation by lowering the ability to manifest a positive ideal L2 self and augmenting L2 disappointment.

Albalawi's (2017) study also implied that relationships could exist between language mindsets and other language-learning variables, one of which is preferences for corrective feedback. To capture the nature of Iranian EFL learners' language mindsets and explore the possible relationship between mindset and feedback preferences, the following research questions were formulated: (a) What are Iranian EFL learners' mindsets about language learning? and (b) How do students' language mindsets relate to their feedback preferences?

\section{Methodology}

\section{Participants}

The population of the study included intermediate EFL learners in Isfahan, Iran, from which a sample of 150 learners was recruited as the participants in this study. The researchers accessed and selected EFL learners from several private language institutes in Isfahan, Iran, who volunteered to take part in the study. They were chosen from among a homogeneous group (in terms of language proficiency) of EFL learners, whose proficiency levels had been assessed through the administration of the Oxford Quick Placement Test (OQPT). Moreover, the participants were native speakers of Persian and included both female (63\%) and male (37\%) language learners. Their exposure to the English language in language institutes ranged from two to five years (with a mean year of exposure of 3.69), and they were aged between 14 and 22. The sample included both high school students (26\%) and university students (74\%). Throughout their academic education both at school and language institutes, they had experienced different types of feedback on their oral and written performances.

\section{Instruments}

The following instruments were employed in this study: OQPT, a language mindsets inventory, and feedback preferences scale. OQPT is an internationally-recognized, standardized test of language proficiency developed to help place students in different proficiency levels. It includes 60 multiple-choice questions assessing the vocabulary, grammar, and reading comprehension of English language learners. This test has been widely used and its reliability and validity were assured by previous researchers. Based on the OQPT scoring rubric, learners who score between 30 and 37 out of 60 are lower intermediate and those who obtain a score between 40 and 47 could be considered upper intermediate. As intermediate EFL learners were the participants of this study, they included those learners who had received a score ranging from 30 to 47 on the OQPT.

The language mindsets inventory (LMI) employed in the current study was an 18-item survey developed by Lou and Noels (2017), which intended to assess learners' language mindsets. This scale measures language mindsets on a 6-point Likert-type scale ranging from 1 (strongly disagree) to 6 (strongly agree). It includes items related to entity mindsets (e.g., You have a certain amount of language intelligence, and you can't really do much to change it) and items related to incremental mindsets (e.g., No matter what you are, you can significantly change your language intelligence level) across the three aspects of language mindsets, including general language intelligence beliefs, second language aptitude beliefs, and age sensitivity beliefs about language learning. Thus, each dimension of language mindsets included three incremental and three entity items. The reliability of the questionnaire was checked through Cronbach's formula and it turned out to be .73. To ensure the validity of the questionnaire, it was handed to three experts in the areas of second language learning, education, and psychology. The experts unanimously approved of the validity of the questionnaire. 
The feedback preferences scale by Saito (1994) was used to assess the participants' preferences for teacher feedback. The scale assesses feedback preferences across several categories including teacher correction, comments, teacher correction with comments, error identification, peer correction, and correction using prompts. The scale includes 23 items on a Likert-type scale as well as a place for writing further suggestions. The scale is among the most highly used and highly cited scales for measuring learners' preferences for corrective feedback.

\section{Data Collection Procedure}

Prior to the commencement of the study, the researcher met a few language institute heads to ask for their permission. In each of the institutes, intermediate classes were listed and the researcher arranged for a placement test to be administered among the intermediate EFL learners who were willing to take part in this study. Among the whole population of EFL learners who were at the intermediate level of language proficiency in those language institutes, which exceeded 800, a total of 150 learners met the criteria of both volunteering and proficiency level (as assess by the OQPT). The learners in the selected sample were given the LMI and the feedback preferences scale to fill out. They were given hard copies of the questionnaires and were asked to return them in a week. Analysis of the data was done through frequency counts, mean scores, and one-sample t-tests for the first research question, and for the other research question, a model of the relations between the language mindsets and feedback preferences was formed and tested using SmartPLS software.

\section{Results}

\section{EFL Learners’ Mindsets about Language Learning}

The first research question of the current study was intended to investigate Iranian EFL learners' mindsets regarding language learning. The required data were collected through the language mindsets inventory, the results of which are displayed in this section. As mentioned above, the language mindsets inventory comprised the three subscales of general language intelligence beliefs (GLB), second language aptitude beliefs (L2B), and age sensitivity beliefs about language learning (ASB), each consisting of an entity and an incremental subcomponent, giving rise to the six subcomponents of GLBENT, GLBINC, L2BENT, L2BINC, ASBENT, and ASBINC, each with three items. These subcomponents are all separately dealt with here. Inasmuch as each choice in this Likert-scale questionnaire carried a point (Strongly agree $=6$, Moderately agree $=5$, Slightly agree $=$ 4, Slightly disagree $=3$, Moderately disagree $=2$, and Strongly disagree $=1$ ), the mean score of each questionnaire item was compared with the average value of the choices (i.e. 3.50). This would mean that if the mean score of a questionnaire item was greater than 3.50, the respondents tended to agree with that statement in the item. On the other hand, a mean score less than 3.50 indicated the respondents' inclination to disagree with a statement mentioned in a questionnaire item.

Table 1

GBLENT Subsection of the Language Mindsets Inventory

\begin{tabular}{|c|c|c|c|c|c|c|c|c|c|}
\hline No. & Statements & $\begin{array}{l}\text { Strongly } \\
\text { agree }\end{array}$ & $\begin{array}{l}\text { Moderately } \\
\text { agree }\end{array}$ & $\begin{array}{l}\text { Slightly } \\
\text { agree }\end{array}$ & $\begin{array}{l}\text { Slightly } \\
\text { disagree }\end{array}$ & $\begin{array}{l}\text { Moderately } \\
\text { disagree }\end{array}$ & $\begin{array}{l}\text { Strongly } \\
\text { disagree }\end{array}$ & Mean & SD \\
\hline 1 & $\begin{array}{l}\text { You have a certain amount of } \\
\text { language intelligence, and you } \\
\text { can't really do much to change it. }\end{array}$ & 8 & 20 & 44 & 28 & 24 & 26 & 3.21 & 1.45 \\
\hline 2 & $\begin{array}{l}\text { Your language intelligence is } \\
\text { something about you that you } \\
\text { can't change very much. }\end{array}$ & 15 & 43 & 12 & 25 & 43 & 12 & 3.506 & 1.57 \\
\hline 3 & $\begin{array}{l}\text { To be honest, you can't } \\
\text { really change your language } \\
\text { intelligence. }\end{array}$ & 28 & 28 & 16 & 35 & 18 & 25 & 3.58 & 1.73 \\
\hline
\end{tabular}

In the GBLENT subsection of the questionnaire, the mean score of the first item $(M=3.21)$ was lower than 3.50, which means that the surveyed EFL learners in this study disagreed that you cannot do much to change your language intelligence. On the other hand, in items \#2 $(M=3.506)$ and $3(M=3.58)$, they agreed that your 
language intelligence is something you cannot change (although the two mean scores for these two items were only slightly higher than the average value of the choices). The total mean score for this part of the questionnaire was 3.43, implying that, on the whole, the learners disagreed that you cannot change your language intelligence. Whether this extent of disagreement was of statistical significance or not could be determined by one-sample t-test results, shown and discussed in Table 7 and in the following pages. For the time being, the results of the GBLINC subcomponent of the questionnaire are presented in Table 2.

Table 2

GBLINC Subsection of the Language Mindsets Inventory

\begin{tabular}{lllllllll}
\hline No. & \multicolumn{1}{c}{ Statements } & $\begin{array}{c}\text { Strongly } \\
\text { agree }\end{array}$ & $\begin{array}{c}\text { Moderately } \\
\text { agree }\end{array}$ & $\begin{array}{c}\text { Slightly } \\
\text { agree }\end{array}$ & $\begin{array}{c}\text { Slightly } \\
\text { disagree }\end{array}$ & $\begin{array}{c}\text { Moderately } \\
\text { disagree }\end{array}$ & $\begin{array}{c}\text { Strongly } \\
\text { disagree }\end{array}$ & Mean \\
\hline $4 \quad \begin{array}{l}\text { No matter who you are, you } \\
\text { can significantly change your } \\
\text { language intelligence level. }\end{array}$ & 36 & 39 & 19 & 21 & 9 & 4.00 & 1.47 \\
$5 \quad \begin{array}{l}\text { You can always substantially } \\
\text { changeyour language intelligence. }\end{array}$ & 22 & 45 & 28 & 27 & 22 & 6 & 4.00 & 1.42 \\
$6 \quad \begin{array}{l}\text { No matter how much language } \\
\text { intelligence you have, you can } \\
\text { always change it quite a bit. }\end{array}$ & 38 & 31 & 25 & 21 & 21 & 14 & 4.01 & 1.65 \\
\hline
\end{tabular}

As shown in Table 2, the mean scores of all of the three items related to the GBLINC subcomponent of the questionnaire turned out to be more than 3.50, indicating that the surveyed EFL learners believed in the incremental nature of language intelligence and concurred that you can change your language intelligence as it is not always fixed. The significance or non-significance of this extent of agreement with the incremental nature of language intelligence will be determined in Table 7. The results of the L2BENT subcomponent of the questionnaire are presented in Table 3.

Table 3

L2BENT Subsection of the Language Mindsets Inventory

\begin{tabular}{|c|c|c|c|c|c|c|c|c|c|}
\hline No. & Statements & $\begin{array}{c}\text { Strongly } \\
\text { agree }\end{array}$ & $\begin{array}{l}\text { Moderately } \\
\text { agree }\end{array}$ & $\begin{array}{c}\text { Slightly } \\
\text { agree }\end{array}$ & $\begin{array}{l}\text { Slightly } \\
\text { disagree }\end{array}$ & $\begin{array}{l}\text { Moderately } \\
\text { disagree }\end{array}$ & $\begin{array}{l}\text { Strongly } \\
\text { disagree }\end{array}$ & Mean & SD \\
\hline 7 & $\begin{array}{l}\text { To a large extent, a person's } \\
\text { biological factors (e.g., brain } \\
\text { structures) determine his or her } \\
\text { abilities to learn new languages. }\end{array}$ & 18 & 23 & 33 & 36 & 19 & 21 & 3.48 & 1.52 \\
\hline 8 & $\begin{array}{l}\text { It is difficult to change how good } \\
\text { you are at foreign languages. }\end{array}$ & 6 & 34 & 23 & 30 & 36 & 21 & 3.20 & 1.65 \\
\hline 9 & $\begin{array}{l}\text { Many people can never do well } \\
\text { in foreign languages even if they } \\
\text { try hard because they lack natural } \\
\text { language intelligence. }\end{array}$ & 21 & 30 & 27 & 30 & 16 & 26 & 3.54 & 1.65 \\
\hline
\end{tabular}

Regarding the L2BENT subsection of the questionnaire, two of the mean scores of the questionnaire items were not higher than the average value of the choices; in fact, the EFL learners did not agree that a person's biological factors determine their abilities to learn a new language (item \# 7,M=3.48), and that it is difficult to change how good you are at foreign languages (item \# $8, M=3.20$ ). Nevertheless, the learners agreed (through to a very small extent) that many people cannot do well in foreign languages because they lack the natural language intelligence (item \# 9, $M=3.54$ ). Whether this amount of disagreement with the fixed nature of L2 learning is of statistical significance will be determined in Table 7. Results of the L2BINC subcomponent of the questionnaire are shown in Table 4 below. 
Table 4

L2BINC Subsection of the Language Mindsets Inventory

\begin{tabular}{|c|c|c|c|c|c|c|c|c|c|}
\hline No. & Statements & $\begin{array}{l}\text { Strongly } \\
\text { agree }\end{array}$ & $\begin{array}{l}\text { Moderately } \\
\text { agree }\end{array}$ & $\begin{array}{l}\text { Slightly } \\
\text { agree }\end{array}$ & $\begin{array}{l}\text { Slightly } \\
\text { disagree }\end{array}$ & $\begin{array}{l}\text { Moderately } \\
\text { disagree }\end{array}$ & $\begin{array}{l}\text { Strongly } \\
\text { disagree }\end{array}$ & Mean & SD \\
\hline 10 & $\begin{array}{l}\text { You can always change your } \\
\text { foreign language ability. }\end{array}$ & 21 & 40 & 33 & 22 & 18 & 16 & 3.84 & 1.54 \\
\hline 11 & $\begin{array}{l}\text { In learning a foreign language, } \\
\text { if you work hard at it, you will } \\
\text { always get better. }\end{array}$ & 27 & 48 & 20 & 20 & 28 & 7 & 4.03 & 1.53 \\
\hline 12 & $\begin{array}{l}\text { How good you are at using a } \\
\text { foreign language will always } \\
\text { improve if you really work at it. }\end{array}$ & 29 & 34 & 28 & 32 & 20 & 7 & 3.99 & 1.47 \\
\hline
\end{tabular}

All the mean scores for the questionnaire items in the L2BINC subsection of the questionnaire represented values greater than the average value of the choices. Hence, the surveyed EFL learners expressed their agreement with the contention that you can always improve your language-learning ability if you work hard at it. Results of the ASBENT subcomponent of the questionnaire are shown in Table 5.

Table 5

ASBENT Subsection of the Language Mindsets Inventory

\begin{tabular}{|c|c|c|c|c|c|c|c|c|c|}
\hline No. & Statements & $\begin{array}{c}\text { Strongly } \\
\text { agree }\end{array}$ & $\begin{array}{c}\text { Moderately } \\
\text { agree }\end{array}$ & $\begin{array}{c}\text { Slightly } \\
\text { agree }\end{array}$ & $\begin{array}{l}\text { Slightly } \\
\text { disagree }\end{array}$ & $\begin{array}{l}\text { Moderately } \\
\text { disagree }\end{array}$ & $\begin{array}{l}\text { Strongly } \\
\text { disagree }\end{array}$ & Mean & SD \\
\hline 13 & $\begin{array}{l}\text { How well a person speaks a } \\
\text { foreign language depends on how } \\
\text { early in life at he/she learned it. }\end{array}$ & 24 & 33 & 36 & 27 & 14 & 16 & 3.85 & 1.53 \\
\hline 14 & $\begin{array}{l}\text { People can't really learn a new } \\
\text { language well after they reach } \\
\text { adulthood. }\end{array}$ & 10 & 28 & 27 & 25 & 36 & 24 & 3.19 & 1.53 \\
\hline 15 & $\begin{array}{l}\text { Even if you try, the skill level you } \\
\text { achieve in a foreign language will } \\
\text { advance very little if you learn it } \\
\text { when you are an adult. }\end{array}$ & 18 & 26 & 26 & 24 & 28 & 28 & 3.32 & 1.64 \\
\hline
\end{tabular}

The first questionnaire item in the ASBENT subsection of the questionnaire had a mean score higher than 3.50; through this item, the respondents expressed their agreement with the claim that language proficiency hinges upon the age when a learner learns a foreign language (item \# 13, $M=3.85$ ). However, for the other two items here, the surveyed learners disagreed that a language cannot really be learned well in adulthood (item \# 14, $M=$ 3.19), and that language skills improve very little in adulthood (item \# $15, M=3.32$ ). The last questionnaire subsection, i.e., that of the ASBINC dimension, and the students' responses are reproduced in Table 6 .

Table 6

ASBINC Subsection of the Language Mindsets Inventory

\begin{tabular}{|c|c|c|c|c|c|c|c|c|c|}
\hline No. & Statements & $\begin{array}{l}\text { Strongly } \\
\text { agree }\end{array}$ & $\begin{array}{l}\text { Moderately } \\
\text { agree }\end{array}$ & $\begin{array}{l}\text { Slightly } \\
\text { agree }\end{array}$ & $\begin{array}{l}\text { Slightly } \\
\text { disagree }\end{array}$ & $\begin{array}{c}\text { Moderately } \\
\text { disagree }\end{array}$ & $\begin{array}{l}\text { Strongly } \\
\text { disagree }\end{array}$ & Mean & SD \\
\hline 16 & $\begin{array}{l}\text { Everyone could do well in foreign } \\
\text { language if they try hard, whether } \\
\text { they are young or old. }\end{array}$ & 24 & 36 & 32 & 27 & 25 & 6 & 3.92 & 1.44 \\
\hline 17 & $\begin{array}{l}\text { How well a person learns a foreign } \\
\text { language does not depend on age; } \\
\text { anyone who works hard can be a } \\
\text { fluent speaker in that language. }\end{array}$ & 25 & 43 & 21 & 22 & 27 & 12 & 3.87 & 1.59 \\
\hline 18 & $\begin{array}{l}\text { Regardless of the age at which } \\
\text { they start, people can learn } \\
\text { another language well. }\end{array}$ & 33 & 24 & 28 & 27 & 26 & 12 & 3.83 & 1.61 \\
\hline
\end{tabular}

The three questionnaire items in the last subsection of the questionnaire received mean scores above the average value of the choices. More exactly, the surveyed EFL learners believed that everyone, irrespective of their age, can do well at foreign language learning if they try hard (item \# 16, $M=3.92$ ), that success in learning another language depends more on how much you try more than it does on your age (item \# 17, $M=3.87$ ), and 
that people can learn an L2 regardless of the age at which they start (item \# $18, M=3.83$ ). The overall mean of the ASBINC subsection of the questionnaire equaled 3.87, which indicates the respondents' agreement with the incremental nature of language learning regardless of the age at which one starts learning a foreign language. The significance or non-significance of the results obtained for the GBLENT, EBLINC, L2BENT, L2BINC, ASBENT, and ASBINC subcomponents of the questionnaire are determined in Table 7 below.

Table 7

One-sample T-test Results for the Language Mindsets Inventory

\begin{tabular}{lcccccc}
\hline & \multicolumn{7}{c}{ Test Value = 3 } \\
\cline { 2 - 7 } & $\mathbf{t}$ & $\mathbf{d f}$ & Overall Mean & Sig. (2-tailed) & 95\% Confidence Interval of the Difference \\
\cline { 2 - 7 } & -.60 & 2 & 3.43 & .60 & Lower & Upper \\
\hline GBL Entity & 151.00 & 2 & 4.003 & .00 & .55 & .41 \\
GBL Incremental & -.89 & 2 & 3.40 & .46 & -.54 & .51 \\
L2B Entity & 7.83 & 2 & 3.95 & .01 & .20 & .35 \\
L2B Incremental & -.23 & 2 & 3.45 & .83 & -.91 & .70 \\
ASB Entity & 14.34 & 2 & 3.87 & .00 & .26 & .82 \\
ASB Incremental & -.94 & 8 & 3.43 & .37 &. .23 & .48 \\
Entity Mindsets & 16.82 & 8 & 3.94 & .00 & .38 & .10 \\
Incremental Mindsets & & & & & .50 \\
\hline
\end{tabular}

Table 7 shows that for the GBL, L2B, and ASB subcomponents of the language mindsets questionnaire, the mean scores for the entity items were (though not significantly) lower than 3.50 , while the ones for the incremental items were significantly higher than the average value of the choices. Moreover, the entity-mindset beliefs (as a whole) had a lower-than-average mean score that did not reach statistical significance, but the incremental-mindset beliefs received a mean score of 3.94, which was found to be significantly higher than the average value of the choices.

\section{Relationship Between Mindsets and Feedback Preferences}

The second research question of the study was formulated to find out the possible relationships between the language mindsets (entity and incremental in this case) of Iranian EFL learners and their feedback preferences in writing. Structural equation modeling (SEM) in SmartPLS was run to find answers to this question. Before presenting the results of this SEM analysis, it is useful to note that the criteria mentioned in Table 8 should be kept in mind and the results of the analysis should be compared with these criteria.

Table 8

Criteria for Evaluating the Variables and Indicators in SmartPLS SEM

\begin{tabular}{|c|c|c|c|}
\hline Model & Evaluation & Criterion & Range \\
\hline \multirow{7}{*}{$\begin{array}{l}\text { Reflective } \\
\text { Measurement Model }\end{array}$} & \multirow[t]{2}{*}{ Convergent Validity } & Outer Loadings & $>.40$ \\
\hline & & Average Variance Extracted (AVE) & $>.50$ \\
\hline & \multirow{3}{*}{$\begin{array}{l}\text { Discriminant } \\
\text { Validity }\end{array}$} & Cross Loadings & Higher Coefficients of Indicators \\
\hline & & Fornell-Larcker & Higher Coefficients for AVE Squared \\
\hline & & HTMT & $<.90$ \\
\hline & \multirow[t]{2}{*}{ Reliability } & Cronbach's Alpha & $>.70$ \\
\hline & & Composite Reliability & $>.70$ \\
\hline \multirow{3}{*}{$\begin{array}{l}\text { Reflective } \\
\text { Measurement Model }\end{array}$} & \multirow[t]{3}{*}{ Validity } & Convergent Validity (Redundancy Analysis) & $>.70$ \\
\hline & & Collinearity of Indicators & $\begin{array}{l}\text { VIF }<5 \\
\text { Tolerance }>.20\end{array}$ \\
\hline & & Significance and Relationships of Outer Weights & $t>1.96$ \\
\hline
\end{tabular}


SHIMA VAGHEI, FARIBA RAHIMI ESFAHANI, SAJAD SHAFIEE

\begin{tabular}{|c|c|c|c|}
\hline Model & Evaluation & Criterion & Range \\
\hline \multirow[t]{6}{*}{ Structural Model } & Testing Hypotheses & Magnitude and Significance of Path Coefficients & $\begin{array}{l}\mathrm{t}>11.96 \\
.025=\text { weak, } .50=\text { moderate, } .75= \\
\text { strong }\end{array}$ \\
\hline & $\begin{array}{l}\text { Model Evaluation } \\
\text { Quality }\end{array}$ & $\mathrm{R}^{2}$ & $\begin{array}{l}.19=\text { weak, } .33=\text { moderate, } .67= \\
\text { strong }\end{array}$ \\
\hline & & $\mathrm{F}^{2}$ & $\begin{array}{l}.02=\text { weak, } .15=\text { moderate, } .35= \\
\text { strong }\end{array}$ \\
\hline & & $Q^{2}$ & $\begin{array}{l}.02=\text { weak, } .15=\text { moderate, } .35= \\
\text { strong }\end{array}$ \\
\hline & Goodness-of-fit & SRMR & $<.80$ \\
\hline & & GOF & $\begin{array}{l}.10=\text { weak, } .25=\text { moderate, } .35= \\
\text { strong }\end{array}$ \\
\hline
\end{tabular}

According to the criteria portrayed above, the measurement models (i.e., the relationships between indicators/ items and the latent variables) as well as the structural model (i.e., the relationships between the latent independent and dependent variables) could be examined. The model tested in the current study considered as its independent variables the two types of language mindsets (i.e., entity mindset and incremental mindset), while the dependent variable was feedback preferences, as shown in Figure 1 below.

\section{Figure 1}

The initial model of the relationship between language mindsets and feedback preferences

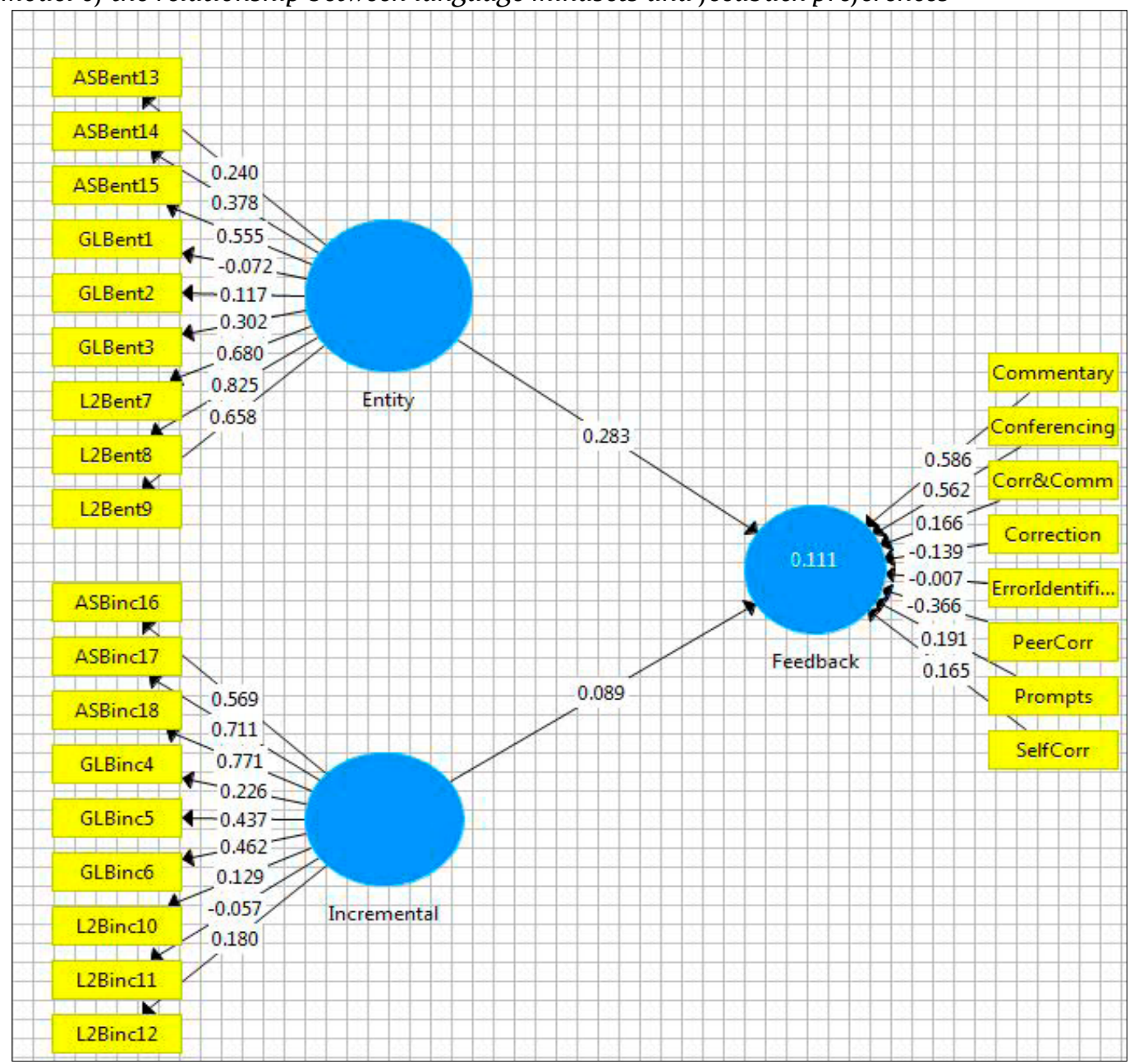

In this initial model, the coefficients of the relationship between the latent variables of the study (i.e., between the independent and dependent variables) are shown. The relationship between these variables is called the 
structural model. The coefficients of the relationships between indicators/items of each latent variable and that given variable are also displayed. These relationships are referred to as the measurement models.

The first criterion in Table 8 is related to the outer weights in the reflective measurement models. It should be noted that the measurement models for entity and incremental mindsets are reflective (since the arrows are drawn from the latent variables towards the indicators) and the measurement model for feedback is formative (as the arrows are drawn from the indicators to the latent variable). Now, the outer weightings of the measurement models should not fall below .40. Thus, indicators 13,14, 1, 2, and 3 in the entity model and indicators $4,10,11$, and 12 in the incremental model were removed from the models. Correction, correction \& commentary, and error identification were also removed from the feedback preferences model since they had very low outer loadings. The whole model was run again and the resulting model is presented in Figure 2 below.

\section{Figure 2}

Second run of the model of the relationship between mindsets and feedback preferences

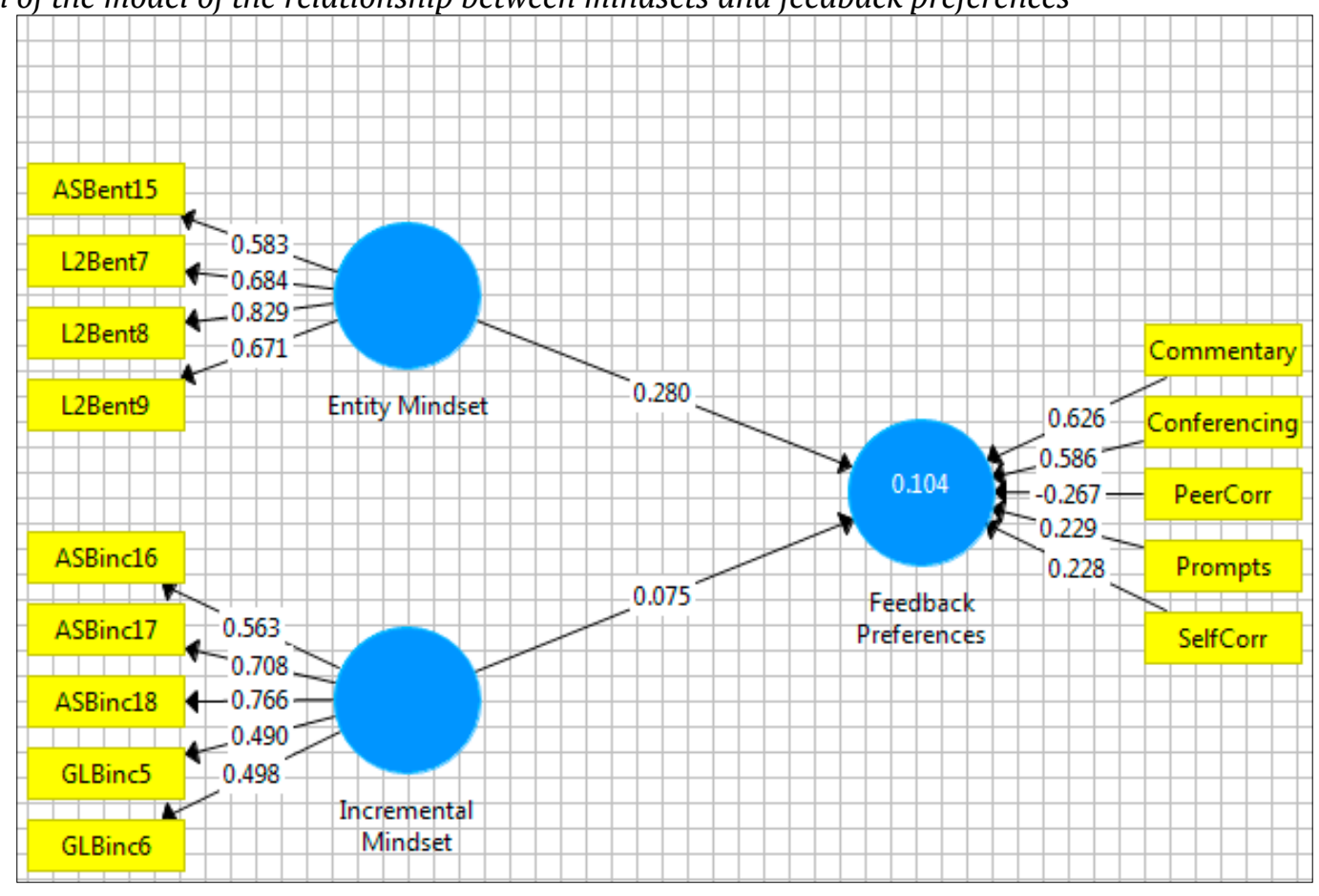

As shown in Figure 2 and Table 9, all the outer loadings for the two measurement models of entity mindset and incremental mindset were greater than .40 , which indicates acceptable outer loadings for the measurement models.

Table 9

Outer Loadings of the Reflective Measurement Models

\begin{tabular}{|c|c|c|}
\hline Indicator & Entity Mindset & Incremental Mindset \\
\hline $\begin{array}{l}\text { Ent07 } \\
\end{array}$ & .70 & \\
\hline Ent08 & .85 & \\
\hline Ent09 & .68 & \\
\hline Ent15 & .53 & \\
\hline Inc05 & & .47 \\
\hline Inc06 & & .49 \\
\hline Inc16 & & .56 \\
\hline Inc17 & & .71 \\
\hline Inc18 & & .77 \\
\hline
\end{tabular}

Table 10 shows the results of convergent validity through AVE. 
Table 10

AVE for the Variables of the Study

\begin{tabular}{lc}
\hline \multicolumn{1}{c}{ Variables } & Entity Mindset \\
\hline Entity Mindset & .48 \\
Incremental Mindset & .37 \\
\hline
\end{tabular}

The AVE values for the entity and incremental mindsets were found to be .48 and .37, respectively, which were not very far below acceptable (i.e., .50). Discriminant validity was examined through cross loadings, the results of which are represented in Table 11 below.

Table 11

Cross Loadings of the Indicators

\begin{tabular}{lcc}
\hline \multicolumn{1}{c}{ Indicator } & Entity Mindset & Incremental Mindset \\
\hline Ent07 & .68 & .34 \\
Ent08 & .82 & .43 \\
Ent09 & .67 & .16 \\
Ent15 & .58 & .32 \\
Inc05 & .21 & .49 \\
Inc06 & .38 & .49 \\
Inc16 & .27 & .56 \\
Inc17 & .26 & .70 \\
Inc18 & .30 & .76 \\
\hline
\end{tabular}

Discriminant validity is achieved if the values for the loadings of the indicators of a given variable are greater than that given variable, compared to the loadings of its indicators with another variable. In Table 11, it can be seen that the coefficients for the relationship between Ent07, Ent08, Ent09, and Ent15 with the entity mindset are greater than the coefficients for the relationship between these indicators and the incremental mindset. On the other hand, the relationships between Inc05, Inc06, Inc16, Inc17, and Inc18 and incremental mindset are stronger than the relationships between these indicators and the entity mindset. Discriminant validity was also checked via the Fornell-Larcker criterion, as presented in Table 12.

Table 12

Results for the Fornell-Larcker Criterion

\begin{tabular}{lccc}
\hline Variables & Entity Mindset & Feedback Preferences & Incremental Mindset \\
\hline Entity Mindset & .69 & & \\
Feedback Preferences & .31 & & \\
Incremental Mindset & .48 & .21 & .61 \\
\hline
\end{tabular}

Since the AVE squared value for the entity mindset is .69, which is greater than its relationship with feedback preferences (.31) and with incremental mindset (.48), it could be claimed that the Fornell-Larcker criterion for the discriminant validity was also met. Another index of discriminant validity was the heterotrait-monotrait (HTMT) ratio, the results of which are provided in Table 13.

Table 13

Results for the HTMT

\begin{tabular}{lcc}
\hline \multicolumn{1}{c}{ Variables } & Entity Mindset & Incremental Mindset \\
\hline Entity Mindset & & .65 \\
Incremental Mindset & .65 & \\
\hline
\end{tabular}

An HTMT ratio of .90 or lower could be deemed as a harbinger of acceptable discriminant validity (Hair, Hult, Ringle, \& Sarstedt, 2017). As the HTMT ratio turned out to be .65, it could be concluded that this criterion of discriminant validity was also met. Regarding the reliability analysis, the results for Cronbach's alpha and composite reliability are shown in Table 14 . 
Table 14

Results for Reliability of the Variables

\begin{tabular}{lcccc}
\hline \multicolumn{1}{c}{ Variables } & Number of Indicators & Cronbach's Alpha & Composite Reliability \\
\hline Entity Mindset & 4 & .65 & .78 \\
Incremental Mindset & 5 & .58 & .74 \\
\hline
\end{tabular}

The results for Cronbach's reliability did not appear to be acceptable since they were lower than .70, but the results for composite reliability, which is a more dependable criterion and does not suffer from the limitations of Cronbach's alpha's reliability, did turn out to be acceptable as they were higher than .70. In what follows, the results for analyzing the formative measurement model are presented (in Tables 15 to 17), followed by the results for the whole structural model.

\section{Table 15}

Collinearity Analysis of the Indicators

\begin{tabular}{lc}
\hline \multicolumn{1}{c}{ Indicators } & Outer VIF Values \\
\hline Ent07 & 1.76 \\
Ent08 & 2.45 \\
Ent09 & 1.61 \\
Ent15 & 1.04 \\
Inc05 & 1.51 \\
Inc06 & 1.56 \\
Inc16 & 1.70 \\
Inc17 & 2.74 \\
Inc18 & 2.15 \\
Commentary & 1.07 \\
Conferencing & 1.06 \\
Peer Correction & 1.07 \\
Prompts & 1.07 \\
Self-correction & 1.03 \\
\hline
\end{tabular}

Because all of the outer VIF values in Table 15 were less than 5.00, and especially the values for commentary, conferencing, peer correction, prompts, and self-correction were far less than 5.00, it could be argued that there was no collinearity among the indicators in the formative measurement model. The formative measurement model was also evaluated by means of examining the outer weights, as portrayed in Table 16.

Table 16

Outer Weights of the Indicators

\begin{tabular}{lc}
\hline \multicolumn{1}{c}{ Indicators } & Outer Weights \\
\hline Commentary & .62 \\
Conferencing & .58 \\
Peer Correction & -.26 \\
Prompts & .22 \\
Self-correction & .22 \\
\hline
\end{tabular}

The values for the outer weights of the indicators of the formative measurement model are presented above. To examine the significance of these outer weights, the Table 17 should be consulted. 
Table 17

Significance of the Outer Weights of the Indicators

\begin{tabular}{lcc}
\hline \multicolumn{1}{c}{ Indicators } & t Statistic & p Value \\
\hline Commentary & 2.72 & .02 \\
Conferencing & 2.22 & .02 \\
Peer Correction & .90 & .36 \\
Prompts & .90 & .36 \\
Self-correction & .83 & .40 \\
\hline
\end{tabular}

Acceptable values for the significance of the outer weights are $t$ values greater than 1.96 (at .05 level of significance) and $p$ values smaller than .05. Among the indicators lined up in Table 17, commentary and conferencing had acceptable $t$ and $p$ values, but there are good reasons (based on the literature on feedback types and regarding the content validity of feedback preferences) to include all other types of feedback listed in the table above as indicators of the variable 'feedback preferences.' The structural model of the study is examined in the following tables.

Table 18

Collinearity of the Variables in the Structural Model

\begin{tabular}{lc}
\hline \multicolumn{1}{c}{ Variables } & Feedback Preferences \\
\hline Entity Mindset & 1.30 \\
Incremental Mindset & 1.30
\end{tabular}

The inner VIF values for entity mindset and incremental mindset equaled 1.30, which is lower than 5.00, indicating that there was no collinearity between the two predictor variables of the model and they could be considered as two separate independent variables. The $R^{2}$ in a model refers to the amount of variance in a dependent variable explained by the variances in the independent variables. This statistic is presented in Table 19.

\section{Table 19}

$R$ Square and Adjusted $R$ Square

\begin{tabular}{ccc}
\hline Variable & R Square & R Square Adjusted \\
\hline Feedback Preferences & .10 & .09 \\
\hline
\end{tabular}

It was previously mentioned in Table 8 that $\mathrm{R}$ square is weak if it is .19 , moderate when it equals .33 , and strong at .67. The R square in the table above was .10, which is weak, indicating that entity and incremental mindsets were weak predictors of feedback preferences. The effect size of either of the independent variables on the dependent variable of the study is shown by $F^{2}$ in the table below.

Table 20

F Square Results

\begin{tabular}{lc}
\hline \multicolumn{1}{c}{ Variables } & Feedback Preferences \\
\hline Entity Mindset & .067 \\
Incremental Mindset & .005 \\
\hline
\end{tabular}

The $F$ square value for entity mindset and incremental mindset were .067 and .005 , respectively. For $F$ square, .02 is weak, .15 is moderate, and . 35 is strong. Thus, the effect size of the entity mindset on feedback preferences was rather weak, and for the incremental mindset, it was very weak. Path coefficients and their significance are examined in Table 21.

Table 21

Path Coefficients

\begin{tabular}{lccc}
\hline \multicolumn{1}{c}{ Variables } & Coefficients & t Statistic & p Value \\
\hline Entity Mindset & .28 & 2.65 & .008 \\
Incremental Mindset & .07 & .53 & .593 \\
\hline
\end{tabular}


For path coefficients, .25 is weak, .50 is moderate, and .75 is strong. Table 21 shows that the entity mindset (.28) and the incremental mindset (.07) were both weak predictors of feedback preferences, but the entity mindset could be a better predictor of feedback preferences than the incremental mindset, and significantly predicted feedback preferences $(t>1.96, p<.05)$. However, incremental mindsets could not significantly predict feedback preferences $(t<1.96, p>.05)$. The $t$ values and the significance/non-significance of the effects could be graphically shown through the bootstrapped graphical representation of the model, as illustrated in Figure 3.

\section{Figure 3}

Significance of the results in the model

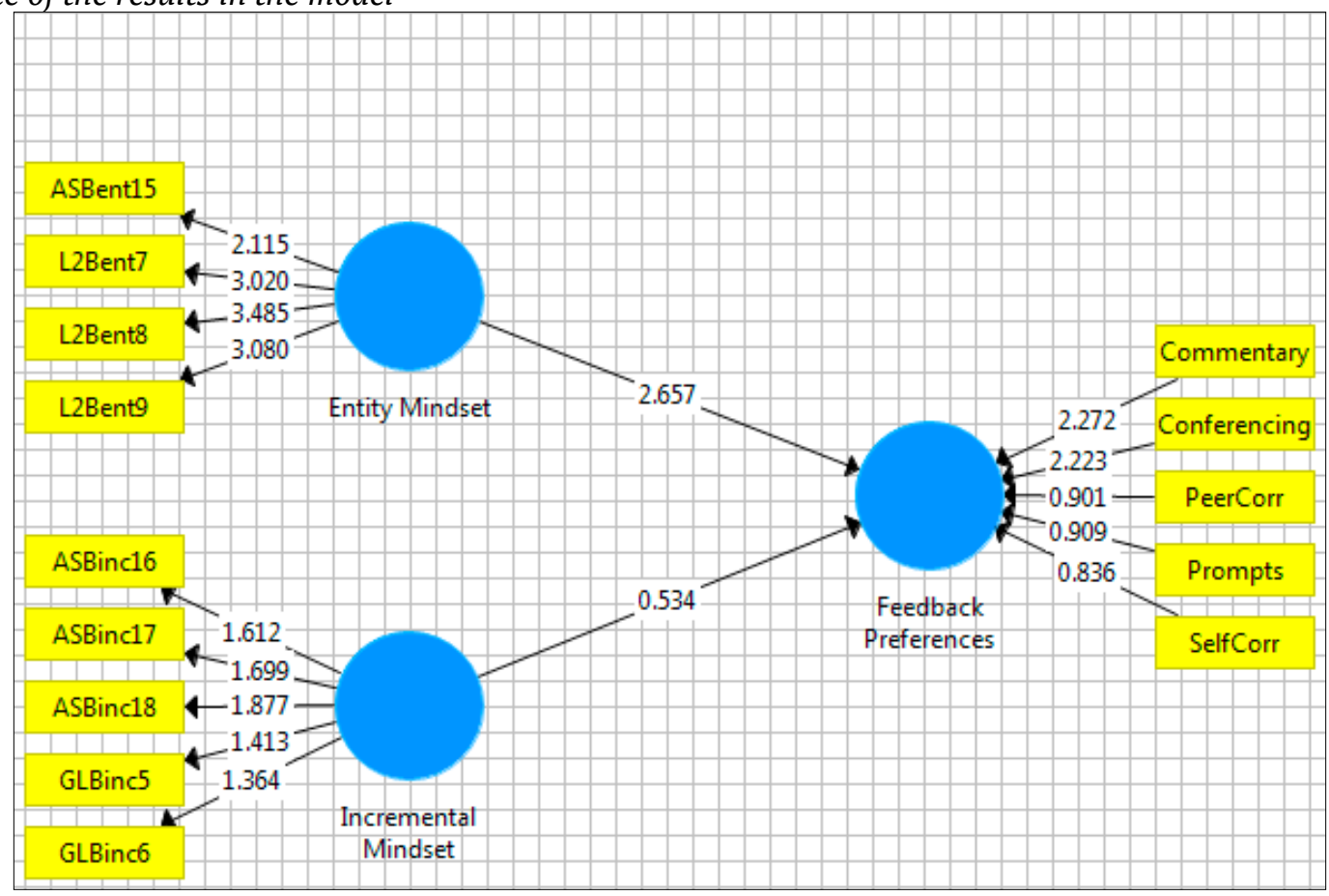

It was mentioned above that $t$ values greater than 1.96 imply a significant effect/relationship. Figure 3 shows that the entity mindset $(t=2.657)$ was a significant predictor of feedback preferences, yet the incremental mindset $(t=.534)$ failed to do so. Finally, the goodness-of-fit of the model was evaluated through the SRMR criterion, and its value was found to be .13; since SRMR values can range between zero and 1.00, and values lower than .08 imply goodness-of-fit of the model, the present model lacked a satisfactory goodness-of-fit.

\section{Discussion}

The results of the first research question of the study unearthed that the surveyed EFL learners agreed with the incremental-mindset beliefs to a significant extent, and disagreed (though not significantly) with the entitymindset beliefs. One reason why the learners in the present study enjoyed more incremental than entity mindsets could be related to the finding of Lou's (2014) study, in which the students who were primed for an incremental mindset, irrespective of their perceived L2 ability, set higher learning goals, expressed more mastery-orientated responses in failure situations, and reported stronger intentions to continue learning the target language (Lou \& Noels, 2016). In the present study, the participants were selected from among those who volunteered to take part in this study and this sampling procedure might have affected the data obtained from them, as those who volunteer to do something may be more interested in it and thus possess attributes that make them different from a typical L2 learner.

However, the results of the first research question contradict the findings of Lou and Noels (2019b) with regard to the effect of language ideology and acceptance of multilingualism in a society on language mindsets. In their study, they concluded that fixed language mindsets may be less common in more multilingual societies. In an 
environment where most people have access to learning and speaking multiple languages, people might be less likely to believe that language-learning ability is fixed. Although the EFL learners of this study do not live in a multilingual society and the only language they speak is Persian, they enjoyed incremental rather than entity mindsets. The reason why this result was obtained could be attributed to the fact that the participants in this study were youngsters aged between 14 and 22, who are among the people labeled Generation Z (alternatively called neo-digital natives), and are characterized by lives integrated with the use of technology and social media. They are usually well-informed, updated, and always connected. Given their immense exposure to global culture and the English language through social media, the internet, satellites, and so forth, even though they are considered monolinguals (in Iran), they are in fact bilingual multicultural beings who have developed open minds capable of capturing the realities behind many matters of which older generations were quite incognizant.

The results are in line with those of Claro et al. (2016) and Destin et al. (2019) in that students from high socioeconomic status backgrounds were more likely to hold incremental mindsets. Since the participants in this study were language learners in private language institutes, they had the economic advantage to afford more opportunities to learn and more access to resources for learning and hence were more likely to develop growth mindsets about their own ability.

At the cultural level, mindsets and achievement-goal orientations may vary across socio-cultural and ethnolinguistic environments (e.g., Dweck et al., 1995; Lou \& Li, 2017; Ryan \& Mercer, 2011). Hence, it is possible that a growth-mindset system is prevalent in countries such as Iran because Iranian culture emphasizes self-criticism and the importance of self-improvement.

The findings of this study also support Lou and Noels' (2019b) belief about the relationship between cognitive capacities and one's mindset. According to Lou and Noels, individual/intrapersonal systems (e.g., cognitive/ affective traits and personal experience) can impact students' mindsets. It is possible that learners' current level of cognitive capacities and the learning environment interactively predict one's mindsets. For example, students with low aptitude levels may be more likely to experience repeated failures, especially in a less supportive environment, and thus are more likely to endorse fixed mindsets. Since the EFL learners in this study were at an intermediate level of proficiency, it can be assumed that they had been partially successful in learning an L2 and hence developed a growth mindset. Differently put, they had climbed several rungs of success in foreign language learning and they probably assumed they could successfully climb the remaining rungs up to the top of the ladder.

Through the second research question of the study, it was found that entity mindsets were a significant predictor of feedback preferences, yet the incremental mindsets failed to do so. Among the feedback types, EFL learners' preferences, in a deductive order, were found to be for commentary and conferencing significantly, and then for peer correction, prompts, and self-correction to a non-significant extent. Besides, the whole model (positing the relationship between entity/incremental mindsets and feedback preferences) lacked satisfactory goodness-of-fit, indicating that the two independent variables (i.e., entity and incremental language mindsets) could not, on the whole, account for the EFL learners' feedback preferences in L2 writing.

Previous research has shown that language mindsets have (causal) relationships with a number of languagelearning variables. As a case in point, Albalawi (2017) found that mindsets played an important part in language learners' motivation, demotivation, remotivation, and resilience/vulnerability. Similarly, Ryan and Mercer (2011) argued that learners' beliefs about the role of natural talent can affect their motivation and their ability to develop a positive identity as a self-directed language learner. Moreover, it has been shown in the literature on language mindsets that mindsets have relationships with other motivational factors such as attribution (Hong et al. 1999), effort beliefs (Lou \& Noel, 2016, 2017), achievement goals (Papi, Rios, Pelt, \& Ozdemir, 2019), self-regulatory tendency in the face of adversity (Lou \& Noel, 2016; Papi, Bondarenko, Wawire, Jiang, \& Zhou, 2019), and competence-based emotional tendencies in the face of adversity (Lou \& Noels, 2019), but it does not mean that language mindsets are bound to have roles and relationships with all other languagelearning variables (such as feedback preferences) for at least two reasons: first, although mindsets are often described as relatively stable beliefs that vary across individuals (Robins \& Pals, 2002), they can vary within an individual over time and across situations; in fact, mindsets are context-specific and may vary according to the context/purpose for which they are used. Second, feedback preferences may be under the influence of other 
factors that could have a more powerful bearing, compared to language mindsets, on those feedback preferences. Some of these more related influences are mentioned in the following paragraphs.

One reason why the EFL learners in this study did not prefer teacher correction, or corrections and comments as preferred ways of receiving feedback, may lie in a finding that was brought up in a study by Johansson (2018), who found that his research participants perceived feedback that is not commonly used by teachers or was used differently by different teachers difficult to interpret. That is, students struggle with interpreting feedback when there are variations in teachers' practices in applying it.

In a study by Lee (2013), advanced ESL learners reportedly received recasts more than any other type of corrective feedback, but they mostly preferred explicit and immediate corrections in the middle of their interchanges and during the teacher-student interactions. The learners in the current study did receive prompts and were shown to welcome this type of feedback, although not significantly. The reason why they would welcome prompts could have its roots in the fact that prompts are less face-threatening than explicit feedback types and reserved learners would prefer to receive prompts than any other type of feedback that could be a threat to their face, as cultural differences may be at work when students choose how to be instructed and treated.

The fact that different groups of students prefer different types of feedback could be attributed to a number of other factors (such as level of proficiency, learning context, and gender, to name a few). Among these factors one can refer to the results of Witt (2019), who found differences in feedback preferences between L1 graduates and L2 graduates, and also between undergraduate students and graduate students. As another example, Roy (2019) found that multilingual writers expected directive explicit feedback from their instructors. They pointed out that audio feedback was better for global commentary and written feedback was better for local commentary. Their perceptions regarding the effectivities of audio and written feedback on their revision process varied depending on their own self-efficacy.

\section{Conclusion}

The present study addressed a niche in the domain of second language-learning mindsets, i.e., the roles of mindsets and their relationships with feedback preferences in writing. The data elicited from 150 intermediate EFL learners unveiled that the participants of this study enjoyed more incremental than entity mindsets in the three areas of general language intelligence beliefs, second language aptitude beliefs, and age sensitivity beliefs about language learning, and their agreements with incremental-mindset items was of statistical significance, while their discord with the entity-mindset items was not statistically significant. It was also found that, on the whole, entity/incremental mindsets could not significantly account for feedback preferences in L2 writing, although entity mindset per se was a significant predictor of feedback preferences. This may have far-fetched implications for language teachers as it is recommended that they seek influential factors (like the ones mentioned above in the Discussion section) other than language mindsets if they intend to work out what makes EFL learners prefer one type of feedback over another. Last but still important, it is recommended that EFL teachers use an amalgamation of different corrective feedback types to appeal to the different needs, styles, and preferences of EFL learners.

\section{Conflict of interests}

The authors declare that they have no conflict of interest. 


\section{References}

Abbaspour, E., Atai, M.R., \& Maftoon, P. (2020). The effect of scaffolded written corrective feedback on Iranian EFL learners' writing quality: An activity theory perspective. International Journal of Foreign Language Teaching and Research, 8(30), 177-196. https://doi.org/10.32038/ltrq.2020.16.01

Albalawi, F. H. E. (2017). L2 demotivation among Saudi learners of English: The role of language learning mindsets [Unpublished doctoral dissertation]. University of Nottingham.

Barcelos, A. M. F. (2003). Researching beliefs about SLA: A critical review. In P. Kalaja \& A. M. F. Barcelos (Eds.), Beliefs about SLA: New research approaches (pp. 7-33). Dordrecht: Kluwer.

Benson, P., \& Lor, W. (1999). Conceptions of language and language learning. System, 27(4), 459-472.

Blackwell, L. S., Trzesniewski, K. H., \& Dweck, C. S. (2007). Implicit theories of intelligence predict achievement across an adolescent transition: A longitudinal study and an intervention. Child development, 78(1), 246-263. https://doi.org/10.1111/j.1467-8624.2007.00995.x

Burnette, J. L., O’Boyle, E. H., VanEpps, E. M., Pollack, J. M., \& Finkel, E. J. (2013). Mind-sets matter: A metaanalytic review of implicit theories and self-regulation. Psychological bulletin, 139(3), 655 -701. https://doi. org/10.1037/a0029531

Carroll, S., Swain, M., \& Roberge, Y. (1992). The role of feedback in adult second language acquisition: Error correction and morphological generalizations. Applied Psycholinguistics, 13(02), 173-198. https://doi. org/10.1016/j.sbspro.2014.03.637

Chaudron, C. (1988). Second language classrooms. Cambridge University Press.

Chiu, C. -Y., Hong, Y. -Y., \& Dweck, C. S. (1997). Lay dispositionism and implicit theories of personality. Journal of Personality and Social Psychology, 73(1), 19-30. https://psycnet.apa.org/doi/10.1037/0022-3514.73.1.19

Cimpian, A., Arce, H. M. C., Markman, E. M., \& Dweck, C. S. (2007). Subtle linguistic cues affect children's motivation. Psychological Science, 18(4), 314-316. https://doi.org/10.1111\%2Fj.1467-9280.2007.01896.x

Claro, S., Paunesku, D., \& Dweck, C. S. (2016). Mindset equals income as a predictor of achievement. Proceedings of the National Academy of Sciences of the United States of America, 113(31), 8664-8668. https://doi.org/ 10.1073/pnas.1608207113

Cohen, A. D., \& Cavalcanti, M. C. (1990). Feedback on compositions: Teacher and student verbal reports. Second language writing: Research insights for the classroom, 13(2), 155-177. https://doi.org/10.1017/ S027226310000992X

Cotterall, S. (1999). Key variables in language learning: What do learners believe about them? System, 27(4), 493-513. https://doi.org/10.1016/S0346-251X(99)00047-0

Destin, M., Hanselman, P., Buontempo, J., Tipton, E., \& Yeager, D. S. (2019). Do student mindsets differ by socioeconomic status and explain disparities in academic achievement in the United States? AERA Open, 5(3). https://doi.org/10.1177\%2F2332858419857706

Diab, R. L. (2005). EFL university students' preferences for error correction and teacher feedback on writing. TESL Reporter, 38(1), 27-51. http://hdl.handle.net/10725/2796

Dweck, C. S. (1999). Self-theories: Their role in motivation, personality, and development. Psychology Press.

Dweck, C. S. (2006). Mindset: The new psychology of success. Random House. https://doi.org/10.4236/ jep.2011.24038

Dweck, C. S. (2007). The perils and promises of praise. Kaleidoscope, Contemporary and Classic Readings in Education, 12, 34-39.

Dweck, C. S. (2019). The choice to make a difference. Perspectives on Psychological Science, 14(1), 21-25. https:// doi.org/10.1177\%2F1745691618804180

Dweck, C. S., Chiu, C. -Y., \& Hong, Y. -Y. (1995). Implicit theories and their role in judgements and reactions: A world from two perspectives. Psychological Inquiry, 6(4), 267-285. https://doi.org/10.1207/ s15327965pli0604_1

Dweck, C. S., \& Leggett, E. L. (1988). A social-cognitive approach to motivation and personality. Psychological review, 95(2), 256. http://dx.doi.org/10.1037/h0037130

Dweck, C. S., \& Molden, D. C. (2007). Self theories: Their impact on competence motivation and acquisition. In A. J. Elliot \& C. S. Dweck (Eds.), Handbook of competence and motivation (pp. 122-140). The Guilford Press.

Ebrahimzade, M. \& Khodareza, M.R. (2016). The effect of hedged-form feedback vs. uncoded feedback on grammatical accuracy of Iranian intermediate EFL learners. International Journal of Foreign Language Teaching and Research, 4(15), 25-33.

Ellis, R. (2006). Researching the effects of form-focused instruction on L2 acquisition. AILA Review, 19, 18-41. 
https://doi.org/10.1075/aila.19.04ell

Ellis, R. (2012). Language teaching research and language pedagogy. Wiley Blackwell.

Ellis, R., S. Loewen \& R. Erlam (2006). Implicit and explicit corrective feedback and the acquisition of L2 grammar. Studies in Second Language Acquisition, 28, 339-368.

Farrokhi, F., Zohrabi, M., \& Chehr Azad, M.H. (2017). The effect of corrective feedback on Iranian EFL learners' speaking accuracy and breakdown fluency. Journal of Language Horizons, 1(2), 107-129.

Ferris, D. R. (1999). The case for grammar correction in L2 writing classes: a response to Truscott (1996). Journal of Second Language Writing, 8(1), 1-11. https://doi.org/10.1016/S1060-3743(99)80110-6

Ferris, D. R. (2004). The «grammar correction» debate in L2 writing: where are we, and where do we go from here? (and what do we do in the meantime...?). Journal of Second Language Writing, 13, 49-62. https://doi. org/10.1016/j.jslw.2004.04.005

Gonzales, M.L.L., de Tejeda, M.L., Krous, J.T., \& Vasquez, D. (2018). EFL teachers' corrective feedback and students' revision in a Peruvian university: A descriptive study. International Journal of Foreign Language Teaching and Research, 6(23), 11-22.

Hair, J.F., Hult, G.T.M., Ringle, C.M., \& Sarstedt, M. (2017). A premier on partial least squares structural equation modeling ( $2^{\text {nd }}$ ed.). Sage.

Halimi, S. S. (2008). Indonesian teachers' and students' preferences for error correction. Wacana, 10(1), 50-71. https://doi.org/10.5539/efl.v4n3p128

Hedgcock, J., \& Lefkowitz, N. (1994). Feedback on feedback: Assessing learner receptivity to teacher response in L2 composition. Journal of Second Language Writing, 3(2), 141-163. https://doi.org/10.1016/10603743(94)90012-4

Hedgcock, J., \& Lefkowitz, N. (1996). Some input on input: Two analyses of student response to expert feedback in L2 writing. The Modern Language Journal, 80(3), 287-308. https://doi.org/10.1111/j.1540-4781.1996. tb01612.x

Hong, Y. Y., Chiu, C. Y., Dweck, C. S., Lin, D. M. S., \& Wan, W. (1999). Implicit theories, attributions, and coping: A meaning system approach. Journal of Personality and Social Psychology, 77(3), 588-599. https://psycnet.apa. org/doi/10.1037/0022-3514.77.3.588

Horwitz, E. K. (1998). The beliefs about language learning of beginning foreign language students. The Modem Language Journal, 72(3), 283-294. https://doi.org/10.1111/j.1540-4781.1988.tb04190.x

Johansson, M. (2018). Formative assessment: Students' attitudes and preferences in Swedish upper secondary school [Unpublished master's thesis]. Orebro University.

Karami, M., \& Heidari Darani, L. (2018). Impact of prompts as corrective feedback strategy on teaching / $/$ / and 1\% among Iranian intermediate EFL learners. International Journal of Foreign Language Teaching and Research, 6(24), 67-82.

Katayama, A. (2007). Japanese EFL students' preferences toward correction of classroom oral errors. Asian EFL Journal, 9, 289-305.

Kelly, G. A. (1955). The Psychology of personal constructs. Norton. http://dx.doi.org/10.1037/11175-008

Lee, E. J. E. (2013). Corrective feedback preferences and learner repair among advanced ESL students. System, 41, 217-230. https://doi.org/10.1016/J.SYSTEM.2013.01.022

Lee, I. (2004). Error correction in L2 secondary writing classrooms: The case of Hong Kong. Journal of Second Language Writing, 13(4), 285-312. https://doi.org/10.1016/j.jslw.2004.08.001

Lee, I. (2005). Error correction in the L2 writing classroom: What do students think? TESL Canada journal, 1-16. https://doi.org/10.18806/tesl.v22i2.84

Leki, I. (1991). The preferences of ESL students for error correction in college-level writing classes. Foreign Language Annals, 24(3), 203-218. https://doi.org/10.1111/j.1944-9720.1991.tb00464.x

Lou, M. T. (2014). Changing language learning mindsets: The role of implicit theories of L2 intelligence for goal orientations and responses to failure [Unpublished master's thesis]. University of Alberts.

Lou, N. M., \& Li, L. M. W. (2017). Interpersonal relationship mindsets and rejection sensitivity across cultures: The role of relational mobility. Personality and Individual Differences, 108, 200-206. https://psycnet.apa.org/ doi/10.1016/j.paid.2016.12.004

Lou, N. M., \& Noels, K. A. (2016). Changing language mindsets: Implications for goal orientations and responses to failure in and outside the second language classroom. Contemporary Educational Psychology, 46, 22-33. https://psycnet.apa.org/doi/10.1016/j.cedpsych.2016.03.004

Lou, N. M., \& Noels, K. A. (2017). Measuring language mindsets and modeling their relations with goal orientations and emotional and behavioral responses in failure situations. The Modern Language Journal, 101(1), 214-243. https://doi.org/10.1016/j.paid.2016.12.004 
Lou, N. M., \& Noels, K. A. (2019a). Sensitivity to language-based rejection in intercultural communication: The role of language mindsets and implications for migrants' cross-cultural adaptation. Applied Linguistics, 40(3), 478-505. https://doi.org/10.1093/APPLIN\%2FAMX047

Lou, N. M., \& Noels, K. (2019b). Does my teacher believe I can improve? Meta-perceptions of potential mediate the effect of teachers' feedback on ESL students' mindsets and need satisfaction. Paper presented at the American educational research association (AERA) conference, Toronto, ON.

Lou, N. M., \& Noels, K. (2019c). Breaking the vicious cycle of language barriers: Growth language-mindsets improve migrant university students' communication experiences [Unpublished doctoral dissertation]. University of Alberta. https://doi.org/10.7939/r3-tnzx-4736

Lou, N. M., \& Noels, K. A. (2020). Breaking the vicious cycle of language anxiety: Growth language mindsets improve lower-competence ESL students' intercultural interactions. Contemporary Educational Psychology, 61, 101847. https://doi.org/10.1016/j.cedpsych.2020.101847

Lyster, R. \& L. Ranta (1997). Corrective feedback and learner uptake: Negotiation of form in communicative classrooms. Studies in Second Language Acquisition, 19, 37-66. https://doi.org/10.1017/S0272263197001034

Lyster, R., Saito, K., \& Sato, M. (2013). Oral corrective feedback in second language classrooms. Language Teaching, 46(01), 1-40. https://doi.org/10.1017/S0261444812000365

McDonough, K. \& Mackey, A. (2000). Communicative tasks, conversational interaction, and linguistic form: An empirical study of Thai. Foreign Language Annals, 33, 82-91. https://doi.org/10.1111/j.1944-9720.2000. tb00893.x

Mercer, S. (2012). Dispelling the myth of the natural-born linguist. ELT Journal, 66(1), 22-29. https://doi. org/10.1093/elt/ccr022

Mercer, S., \& Ryan, S. (2010). A mindset for EFL: Learners' beliefs about the role of natural talent. ELT Journal, 64(4), 436-444. https://doi.org/10.1093/elt/ccp083

Miles, M. B., \& Huberman, A. M. (1984). Qualitative data analysis: A sourcebook of new methods. Sage publications.

Mir, F., \& Ghornavi, K. (2017). Effect of corrective feedback on the acquisition of English prepositions of movement and place in third-grade high school EFL learners' grammar performance. International Journal of Foreign Language Teaching and Research, 5(20), 125-140.

Naeimi, A., Saeidi, M., \& Behnam, B. (2017). Effect of oral corrective feedback on Iranian EFL learners' phonological uptake and retention. International Journal of Foreign Language Teaching and Research, 5(17), 57-75.

Noori Khaneghah, R. (2016). The efficiency of different types of corrective feedback on vocabulary development of Iranian EFL learners: A comparative study. International Journal of Humanities and Cultural Studies, Special January Issue, 1(1), 2534-2548.

Papi, M., Bondarenko, A. V., Wawire, B., Jiang, C., \& Zhou, S. (2019). Feedback-seeking behavior in second language writing: Motivational mechanisms. Reading and Writing, 33, 485-505. https://doi.org/10.1007/ s11145-019-09971-6

Papi, M., Rios, A., Pelt, H., \& Ozdemir, E. (2019). Feedback-seeking behavior in language learning: Basic components and motivational antecedents. The Modern Language Journal, 103(1), 205-226. https://doi. org/10.1111/modl.12538

Ramadhani, S.A.F. (2019). Investigating corrective feedback in speaking practice: Students' preferences. Advances in Social Science, Education, and Humanities Research, 424, 187-192.

Reid, J.M. (1997). Understanding learning styles in the second language classroom. Prentice Hall.

Rennie, C. (2000). Error feedback in ESL writing classes: What do students really want [Unpublished Master's thesis]. California State University.

Rissanen, I., Kuusisto, E., Tuominen, M., \& Tirri, K. (2019). In search of a growth mindset pedagogy: A case study of one teacher's classroom practices in a Finnish elementary school. Teaching and Teacher Education, 77, 204213. https://doi.org/10.1016/j.tate.2018.10.002

Robins, R. W., \& Pals, J. L. (2002). Implicit self-theories in the academic domain: Implications for goal orientation, attributions, affect, and self-esteem change. Self and Identity, 1(4), 313-336. https://doi. org/10.1080/15298860290106805

Robinson, P. (2005). Aptitude and second language acquisition. Annual Review of Applied Linguistics, 25, 46-73. https://doi.org/10.1017/S0267190505000036

Roy, S. (2019). Exploring multilingual writers' preference between audio and written feedback, and the impact of feedback format on their revision process in a U.S. composition class [Unpublished doctoral dissertation]. Indiana University of Pennsylvania. 
Ryan, S., \& Mercer, S. (2011). Natural talent, natural acquisition and abroad: Learner attributions of agency in language learning. In G. Murray, X. Gao \& T. Lamb (Eds.), Identity, motivation and autonomy in language learning (pp. 160-176). Multilingual Matters.

Saito, H. (1994). Teachers' practices and students' preferences for feedback on second language writing: A case study of adult ESL learners. TESL Canada Journal, 11(2), 46-70. https://doi.org/10.18806/tesl.v11i2.633

Schulz, R. A. (1996). Focus on form in the foreign language classroom: Students' and teachers' views on error correction and the role of grammar. Foreign Language Annals, 29, 343-364. https://doi. org/10.1111/j.1944-9720.1996.tb01247.x

Sippel, L. (2019). The impact of peer corrective feedback on vocabulary development. Foreign Language Annals, 52(3), 595-611. https://doi.org/10.1111/flan.12416

Sternberg, R. J. (2002). The theory of successful intelligence and its implications for language aptitude testing. In P. Robinson (Ed.), Individual differences and instructed language learning. John Benjamins Publishing.

Tesnim, O. (2019). Oral corrective feedback and its impacts on learners' speaking skills: Tunisian ESL students as a case study. International Journal of Language and Linguistics, 7(3), 138-149. https://doi.org/10.11648/j. ijll.20190703.15

Truscott, J. (1996). The case against grammar correction in L2 writing classes. Language Learning, 46(2), 327-369. https://doi.org/10.1111/j.1467-1770.1996.tb01238.x

Truscott, J. (1999). The case for "The case against grammar correction in L2 writing classes": A response to Ferris. Journal of Second Language Writing, 8(2), 111-122. https://doi.org/10.1016/S1060-3743(99)80124-6

Wang, P. (2010). Dealing with English majors' written errors in Chinese universities. Journal of Language Teaching and Research, 1(3), 194-205. https://doi.org/10.4304/jltr.1.3.194-205

White, C. (2008). Beliefs and good language learners. In C. Griffiths (Ed.), Lessons from good language learners (pp. 121-130). Cambridge University Press.

Witt, J. (2019). Disciplinary writing feedback practices: Comparing preference, expectations, and practices. [Unpublished doctoral dissertation]. University of Arizona.

Yeager, D. S., \& Dweck, C. S. (2012). Mindsets that promote resilience: When students believe that personal characteristics can be developed. Educational Psychologist, 47(4), 302-314. https://doi.org/10.1080/0046152 0.2012 .722805

Zhai, K., \& Gao, X. (2018). Effects of corrective feedback on EFL speaking task complexity in China's university classroom. Cogent Education, 5(1), 1-13. https://doi.org/10.1080/2331186X.2018.1485472

Zohi Rad, M., \& Ghafournia, N. (2016). The effect of focused corrective feedback and attitude on grammatical accuracy: A study of Iranian EFL learners. International Journal of Foreign Language Teaching and Research, $4(15), 75-85$. 